\title{
First records of remarkable damselfly species Nebalennia speciosa (Odonata: Coenagrionidae) from the Republic of Karelia (Russia)
}

\author{
Первые находки примечательного вида стрекоз Nebalennia \\ speciosa (Odonata: Coenagrionidae) в Респубцике Карелия (Россия)
}

\author{
Andrei Humala ${ }^{1}$, Alexei V. Polevoi \\ Андрей Хумала', Алексей Полевой
}

Forest Research Institute, Russian Academy of Sciences, Pushkinskaya St. 11, Petrozavodsk 185910, Russia. E-mail: humala@krc.karelia.ru Институт леса Карельского научного центра Российской академии наук, ул. Пушкинская 11, г. Петрозаводск 185910 , Россия.

KEY WORDS: distribution, Fennoscandia, new finding, north-west Russia, Odonata, rare species, South Karelia.

КЛЮЧЕВЫЕ СЛОВА: распространение, Фенноскандия, новые находки, СЗ Россия, стрекозы, редкий вид, Южная Карелия.

ABSTRACT: Several local populations of remarkable Odonata species Nehalennia speciosa (Coenagrionidae) are reported for the first time from the Republic of Karelia. N. speciosa is considered a threatened species in Europe even though it is widespread throughout the Palaearctic region. The species was found within several nature protected areas of Karelia, where entomological studies were conducted. The biology and distribution of $N$. speciosa are briefly observed.

РЕЗЮМЕ. Впервые в Республике Карелия зарегистрированы несколько локальных популяций примечательного вида стрекоз Nehalennia speciosa (Coenagrionidae). Несмотря на то, что в Европе $N$. speciosa считается находящейся под угрозой исчезновения, вид широко распространён в Палеарктике. Вид был обнаружен на нескольких природоохранных территориях Карелии, где проводились энтомологические исследования. Кратко рассмотрены биология и распространение N. speciosa.

\section{Introduction}

The order Odonata is a relatively small group of insects with aquatic larvae, comprising 43 species known for Karelia: 14 species of damselflies (Zygoptera) and 29 species of dragonflies (Anisoptera). The Odonata fauna is relatively well studied in Karelia, largely due to the works of Finnish researchers who, from the end of the nineteenth century, published faunistic lists, mainly based on materials collected in the southern regions of the republic [Djakonov, 1922; Tiensuu, 1933; Valle 1920-1952]. However, since that time no special Odo- nata study was conducted in Karelia. Recent publications on Odonata in Karelia contain several new regional records including rather rare species [Humala, 2006; Humala, Polevoi, 2009, 2015; Jakovlev et al., 2014], as well as additions to the Karelian list of dragonflies and damselflies [Polevoi et al., 2009].

During the expedition in 2017, we drew attention on unusually small and slender damselfly, which was identified as Nehalennia speciosa (Charpentier, 1840) - a rare Palaearctic species. In the following years $N$. speciosa was observed in several other localities. In this paper, we provide the data on the finds of this rare damselfly, representing a remarkable addition to the Karelian Odonata fauna.

\section{Material and methods}

This communication is based on authors' observations in South Karelia made during the field seasons 2017-2019 (Fig. 1). Several specimens were collected (stored in the collection of Forest Research Institute KarRC RAS, Petrozavodsk), while the others were just recorded, and some of them photographed in nature.

Results and discussion

$$
\begin{gathered}
\text { Order ODONATA } \\
\text { Family Coenagrionidae }
\end{gathered}
$$

Nehalennia speciosa (Charpentier, 1840)

SPECIES CHARACTERISTIC. Nehalennia speciosa (Charpentier, 1840) or 'pygmy damselfly', 'sedgeling' or 'sedgling', is an Odonata species from the family Coenagrio-

How to cite this article: Humala A., Polevoi A.V. 2020. First records of remarkable damselfly species Nehalennia speciosa (Odonata: Coenagrionidae) from the Republic of Karelia (Russia) // Russian Entomol. J. Vol.29. No.2. P.123-126. doi: 10.15298/rusentj.29.2.01 
nidae. This is the smallest dragonfly species in our fauna: the imago body length is about $2.5 \mathrm{~cm}$, the wing length is 1116 $\mathrm{mm}$; the abdomen is very thin (Figs 2-3). Wings are transparent and do not extend beyond the fifth segment of the abdomen. The colour of the male is mainly metallic green, with elements of blue (a transverse stripe behind the eyes, sides of the thorax, top and bottom of the abdomen). Two colour forms are known in females: one the same as of the male, the second bronze-green, and the blue colour is replaced by yellowish-green or reddish-brown. The legs are black to whitish. The colouration and appearance of $N$. speciosa resemble much more common damselflies of the genus Lestes, but easily distinguished by its smaller size, short stigma, and the fact that at rest it keeps its' wings folded.

BIOLOGICAL AND ECOLOGICAL PECULIARITIES. Nehalennia speciosa is a stenotopic, low numbered species. Larvae live in the coastal zone of small water bodies, within bogs of various types. It is characterized as "an oligotrophic and acidophilous, occurring on peat bogs or along shallow bogged margins of glacial lakes formed by floating Sphagnum mats and covered with medium-dense stands of narrowleaved sedges (Carex limosa, C. paupercula and C. lasiocar$p a$; thickets $30-80 \mathrm{~cm}$ high), and other plants of similar appearance such as Rhynchospora, Scheuchzeria etc.", in the thickets of which adult dragonflies are occurring [Bernard, Kosterin, 2008, etc.]. Less commonly, the species is observed in "secondary" biotopes in ponds, swampy meadows [Bernard, Wildermuth, 2005; Kalninš et al., 2011, etc.] and semiaquatic thickets. One generation developing per year. Adults occur from June to early August and as a rule do not fly far away from the habitats, where its larvae develop [Bernard, Wildermuth, 2005, Schmidt, Sternberg, 1999].

DISTRIBUTION. N. speciosa is distributed throughout the whole Palaearctic region from Portugal to Japan [Doucet, Jacquot, 2012, GBIF.org, 2020]. It occurs mainly on the plains and only within a relatively narrow latitudinal stripe in Europe, limited between $39^{\circ} \mathrm{N}$ and $62^{\circ} \mathrm{N}$ [Bernard, Wildermuth, 2005, etc.]. The range is strongly fragmented and represented by separate isolated localities, confined mainly to the Pleistocene glaciation sites [Bernard, Wildermuth, 2005].

It is known in Russia from a number of regions in the middle zone of the European part (Kirov, Nizhny Novgorod, Pskov, Smolensk, Ivanovo, Tula Prov., Mordovia) [Bernard, Wildermuth, 2005; Skvortsov, 2010; GBIF.org, 2020, etc.], in the Southern Urals [Haritonov, Eremina, 2010], in the southern part of Western Siberia, and in the south of the Far East [Bernard, Wildermuth, 2005; Kosterin et al., 2001; Bernard, Kosterin, 2008]. In the Leningrad Province, it is known by single imago specimen collected in the first half of the 20th century in the Tosno District and also reported from the vicinity of Peterhoff at the beginning of the 20th century [Przhiboro, 2018].

Concerning the distribution of this species in Russia we refer also to the Atlas "The dragonflies of Eastern Europe and Caucasus" by Skvortsov [2010]. The distribution map of $N$. speciosa covers there the Karelian territory by hatchwork, meaning that "no faunistic data or those are scanty and insufficient to define the distribution pattern. Although, judging by indirect data, the species should be present in province, no suggestion on its occurrence can be made; most likely the species is rare or irregularly spread" [Skvortsov, 2010]. However, at the same time, the territory of Estonia, where this species widespread and there are a lot of welldocumented observations from the 19th century (Fig. 4) is marked by the same hatching as Karelia. Taking into account

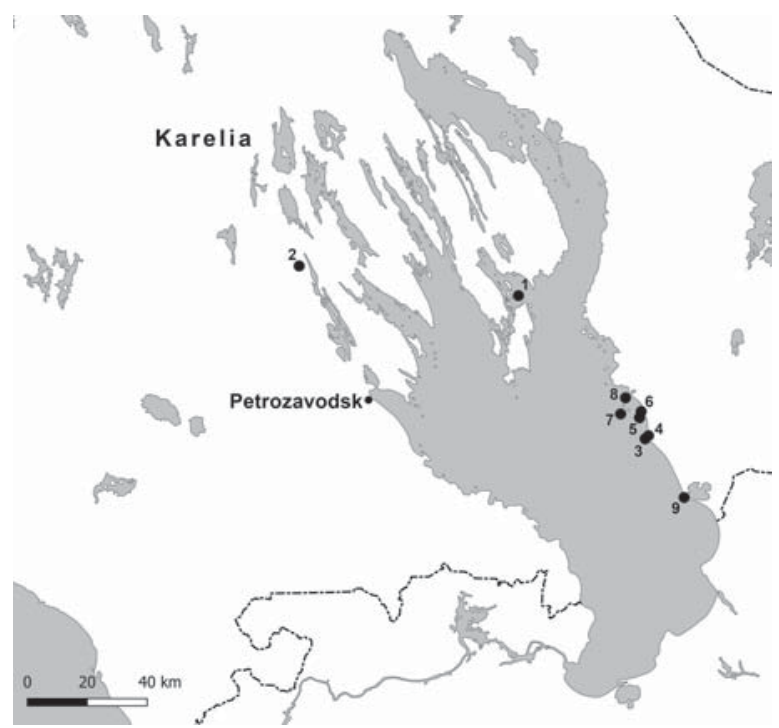

Fig. 1. Collecting localities of N. speciosa in Karelia in 20172019: 1 - Dolgiy Isl.; 2 - $2 \mathrm{~km} \mathrm{SE}$ of Tereki; 3 - the mouth of Chernaya Rechka R.; 4 - Besov Nos; 5 - Mikhailovets Isl.; 6 Cherny Cape; 7 - Bolshoy Golets Isl.; 8 - Sosnovets Isl.; $9-1.5$ $\mathrm{km}$ E of Muromskiy monastery.

Рис. 1. Местонахождения N. speciosa в Карелии в 2017-2019 гг.: 1 - о. Долгий; 2 - 2 км юго-восточнее д. Тереки; 3 - устье p. Чёрная речка; 4 - д. Бесов Нос; 5 - о. Михайловец; 6 - мыс Чёрный; 7 - о. Большой Голец; 8 - о. Сосновец; $9-1,5$ км к востоку от Муромского монастыря.

the absence of any records from the adjacent territories of the Arkhangelsk, Vologda and Leningrad Provinces, such disjunction in the range of $N$. speciosa does not look true. So this approach seems to be unjustified, and providing of such distribution maps is not a good choice.

THREAT STATUS. In spite of wide range, $N$. speciosa is rather rare species and classified as Near Threatened in the IUCN European Red List [Kalkman et al., 2010]. It is threatened by habitat loss (declining and pollution of swamps, freshwater marshes, and open excavations). The species is included in national Red Data Books of some European countries, for instance, Finland [Karjalainen, 2019], Latvia [Kalninš et al., 2011], etc., and several Red Data Books of Russian regions: Leningrad Province [Przhiboro, 2018], Ivanovo Province [Tikhomirov, 2007], Tula Province [Bolshakov, 2014].

MATERIAL STUDIED. Russia, Karelia: Medvezh'egorskiy District, Kizhskiy Reserve, Dolgiy Island, swamped lake shore, $62.104^{\circ} \mathrm{N}, 35.279^{\circ} \mathrm{E}, 4$.VII.2017, 1 \%; Kondopozhskiy District, 2 $\mathrm{km} \mathrm{SE}$ of Tereki, $62.215^{\circ} \mathrm{N}, 33.869^{\circ} \mathrm{E}$, herb-rich mixed forest, 25.VI.2018, $1 \mathrm{O}^{7}$; Pudozhskiy District, near the mouth of Chernaya Rechka River, forest glade (road side), $61.670^{\circ} \mathrm{N}, 36.055^{\circ} \mathrm{E}$, 3.VII.2018, $10^{7}$; Pudozhskiy District, Besov Nos, abandoned meadow, $61.673^{\circ} \mathrm{N}, 36.053^{\circ} \mathrm{E}, 4$.VII.2018, 1 ; ; Pudozhskiy District, Mikhailovets Island, rocky lake shore, $61.729^{\circ} \mathrm{N}, 36.013^{\circ} \mathrm{E}$, 7.VII.2018, 1 B\&; Pudozhskiy District, Cherny Cape, meadow near the lake shore, $61.748^{\circ} \mathrm{N}, 36.026^{\circ} \mathrm{E}, 7 . \mathrm{VII} .2018,1 \mathrm{O}^{\mathrm{T}}$; Pudozhskiy District, Bol'shoy Golets Island, meadow along the lake shore, $61.744^{\circ} \mathrm{N}, 35.896^{\circ} \mathrm{E}, 8 . \mathrm{VII} .2018,2 \mathrm{O}^{\mathrm{T}} 1$ \% ; Pudozhskiy District, Sosnovets Island, rocky lake shore, $61.792^{\circ} \mathrm{N}, 35.929^{\circ} \mathrm{E}, 8$.VII.2018, $1 \mathrm{~B} \&$; Pudozhskiy District, $1.5 \mathrm{~km} \mathrm{E}$ of Muromskiy monastery, abandoned meadow, $61.484^{\circ} \mathrm{N}, 36.268^{\circ} \mathrm{E}, 7 . \mathrm{VII} .2019,1$ ․

Thus there are at least several probably isolated populations of $N$. speciosa on the territory of Southern Karelia. The Karelian localities are the northernmost 

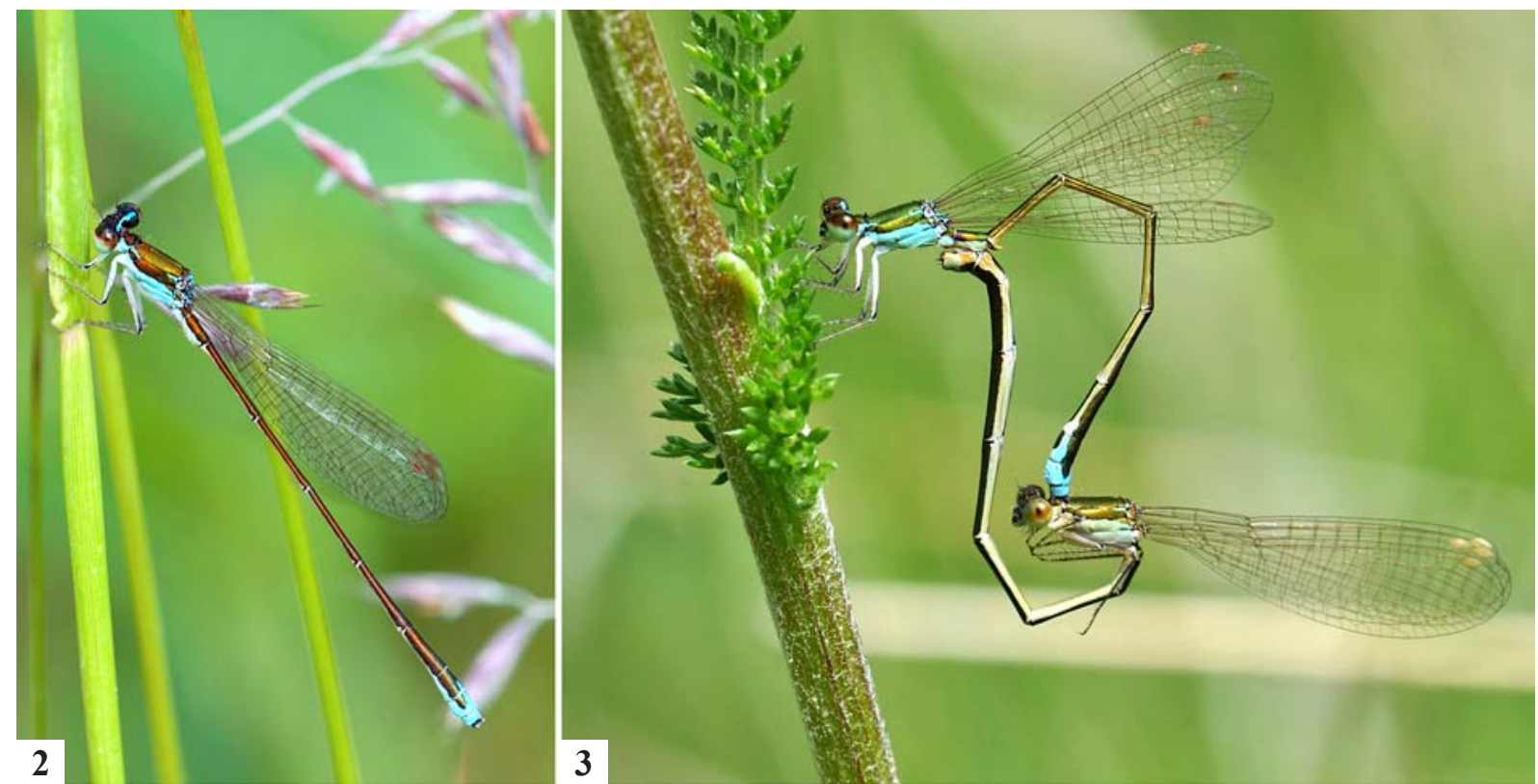

Figs 2-3. Nehalennia speciosa: 2 - male; 3 - pair in copula.

Рис. 2-3. Nehalennia speciosa: 2 - самец; 3 - тандем.

points, so the northern range limit of the species has changed considerably (up to $62^{\circ} \mathrm{N}$ ) in comparison with previous records from Fennoscandia [GBIF.org 2020]. Almost all localities are situated within nature protected areas: Kizhsky State Nature Reserve (1), State complex (landscape) regional reserve "Muromskiy" (39) which will undoubtedly be a benefit for preserving habitats and subsequent populations monitoring of this species.

Our observations also reveal some interesting peculiarities of $N$. speciosa populations in Karelia. The collecting locality near Tereki (2) is situated in the forest biotope, more than $1 \mathrm{~km}$ from the nearest waterbody with an elevation exceeding $100 \mathrm{~m}$ above lake water level. Another location (the meadow east of
Muromskiy monastery) is over $300 \mathrm{~m}$ distant from the nearest lake or river. This indicates a potentially higher dispersal ability of $N$. speciosa than was initially thought.

Other interesting observations are the findings of $N$. speciosa on small islands in Onego Lake. And if Mikhailovets Island (3) is located in $1.75 \mathrm{~km}$ from the mainland, the Bol'shoy Golets Island (4) is $6.8 \mathrm{~km}$ away from the mainland. It is difficult to imagine, that these tiny damselflies with weak flight ability could cover such distances even under favourable weather conditions. So it seems more probable that this species occurs there permanently and larvae development is also taking place close to the coastal zone or maybe in the puddles or small ponds forming after strong lake storms. It is also noteworthy that

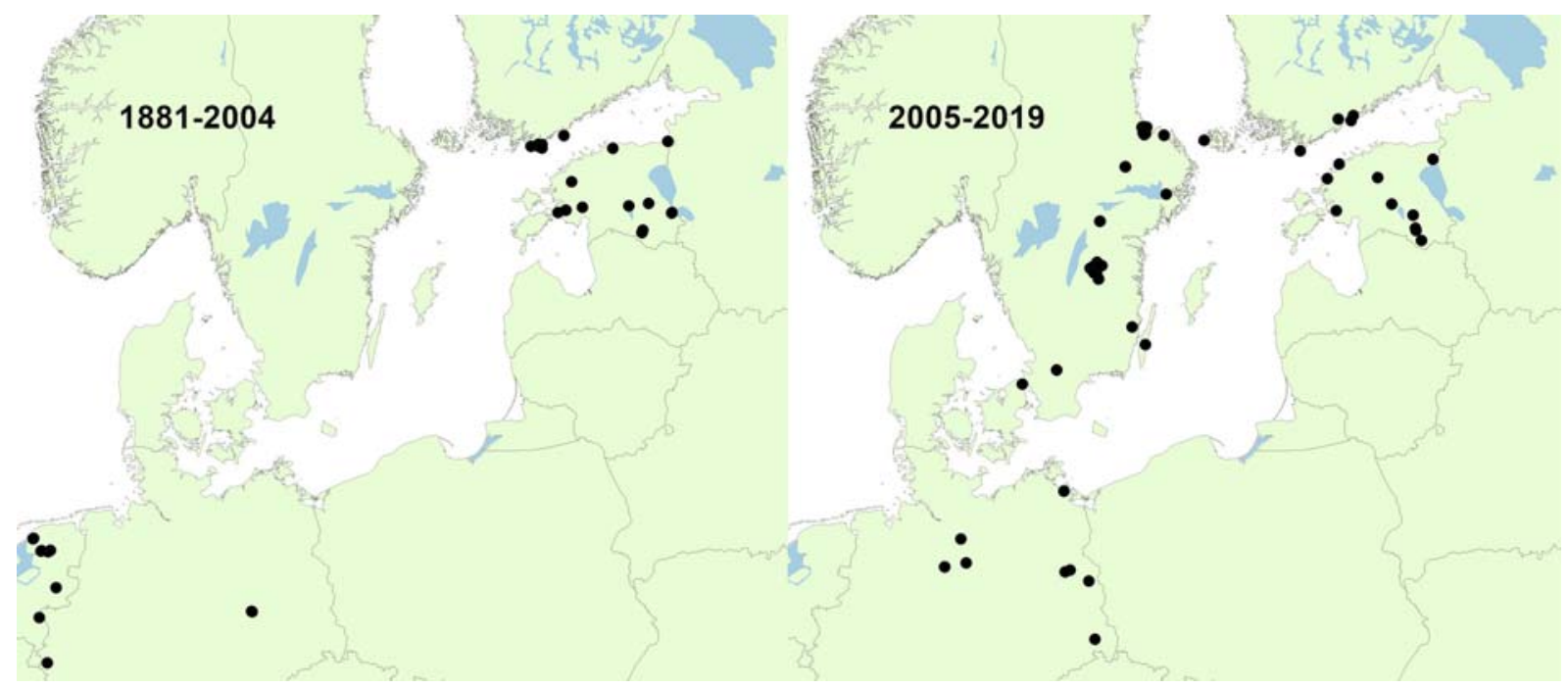

Fig. 4. Occurrences of N. speciosa in north Europe before 2005 and from 2005 onwards [from GBIF.org, 2020].

Pис. 4: Распространение N. speciosa в Северной Европе до 2005 года и после 2005 года [по: GBIF.org, 2020]. 
another relict Odonata species Coenagrion armatum (Charpentier, 1840) was also recorded by us on the Onego Lake islands in the same habitats as $N$. speciosa.

In neighbouring Finland, all known findings of $N$. speciosa are located in extreme South-West of the country, along Baltic Sea shore [Valtonen, 1980; Karjalainen, 2007]. According to the GBIF data, the species was reported from Finland since 1934 [GBIF.org, 2020], however, then it has not been observed in the country during 21 years and found again only in 2002 [Arnaboldi, 2003]. The species was also considered extinct in Sweden and Italy, but then was rediscovered [Karlsson, 2011, Aguzzi et al., 2017]. In Sweden, North-East Germany and to a lesser extent Finland N. speciosa became more common during the recent years (Fig. 4) and the number of its observations increased.

Being relatively small, $N$. speciosa attracts the observer attention in nature, looking as something unusual comparing to more common species like e.g. Lestes spp. Considering long flight period (since mid-June till the end of August), there is only little chance that it was overlooked during rather intensive entomological studies conducted in Karelia in the last 30 years. We hence believe this species is a real newcomer. Basing on our data it is reasonable to assume, that $N$. speciosa arrived in Karelia from the South-East, however this species was not reported from the neighbouring areas, such as the Arkhangelsk and Vologda Provinces, where the fauna of Odonata is poorly known.

CONCLUSIONS. Nowadays altogether there are 44 species of Odonata known for the territory of Karelia and 15 species of them are damselflies (Zygoptera). The recently discovered species $N$. speciosa should be included in the regional Red Data Book and all revealed populations need to be monitored. The newly found Karelian localities are the northernmost points, expanding the range of this species. It would be interesting to clarify the origin of the Karelian populations and to confirm the presence of this species in the adjacent territories South-East of Karelia.

Acknowledgements. The study was carried out under state order to the Karelian Research Centre of the Russian Academy of Sciences (Forest Research Institute).

\section{References}

Aguzzi S., Bogliani G., Orioli V., Pilon N. 2017. Nehalennia speciosa rediscovered in northwestern Italy (Odonata: Coenagrionidae) // Notulae odonatologicae. Vol.8. No.9. P.319-374.

Arnaboldi F. 2003. Observation récente de Nehalennia speciosa (Charpentier, 1840) en Finlande. Note sur son habitat // Martinia. Vol.19. No.3. P.109-118.

Bernard R., Kosterin O.E., 2008. Field notes of two hunters for Nehalennia speciosa in boggy Vasyugan Plain, West Siberia // IDF-Report. No.12. P.134.

Bernard R., Wildermuth H. 2005. Nehalennia speciosa (Charpentier, 1840) in Europe: A case of a vanishing relict (Zygoptera: Coenagrionidae) // Odonatologica. Vol.34. No.4. P.335-378.

Bolshakov L.V. 2014. [Nehalennia speciosa] // Red Data Book of Tula Province. Animals. Accessed at: http://redbooktula.ru/ krasnaya-kniga/strekozy-odonata/strelka-krasivaya [in Russian].

Djakonov A.M. 1922. [On the fauna of Odonata of lake Sandal and its surroundings] // Trudy Olonetskoy nauchnoy ekspeditsii. Pt.6.
Zoologia. No.1. P.3-37 [in Russian, with English summary].

Doucet G., Jacquot P. 2012. Éléments sur l'émergence et les exuvies de Nehalennia speciosa (Charpentier, 1840) en France (Odonata, Zygoptera: Coenagrionidae) // Martinia. Vol.28. No.2. P.83-88.

GBIF.org 2020. GBIF Occurrence. Accessed at: https://doi.org/ 10.15468/dl.yvd7b6.

Haritonov A.Yu., Eremina E.E. 2010. [The dragonflies (Odonata) of South Ural: the value of regional faunistic research] // Eurasian Entomological Journal. Vol.9. No.2. P.263-273 [in Russian].

Humala A.E. 2006. [On the insect fauna of "Kivach" Nature Reserve] // Trudy Karel'skogo nauchnogo tsentra RAN. Priroda zapovednika "Kivach". No.10. P.153-159 [in Russian].

Humala A.E., Polevoi A.V. 2009. [On the insects fauna of south-east Karelia] // Trudy Karel'skogo nauchnogo tsentra RAN. Biogeographia Karelii. No.4. P.53-75 [in Russian].

Humala A.E., Polevoi A.V. 2015. Records of rare and noteworthy insect species (Insecta) in the Republic of Karelia // Trudy Karel'skogo nauchnogo tsentra RAN. Biogeographia Karelii. No.6. P.19-46 [in Russian]. DOI: 10.17076/bg30.

Jakovlev J., Polevoi A., Humala A. 2014. Insect fauna of Zaonezhye Peninsula and adjacent islands // T. Lindholm, J. Jakovlev, A. Kravchenko (eds.). Biogeography, landscapes, ecosystems and species of Zaonezhye Peninsula, in Lake Onega, Russian Karelia. Reports of the Finnish Environment Institute. Helsinki: Finnish Environment Institute. P.257-338.

Kalkman V.J. 2010. Nehalennia speciosa. The IUCN Red List of Threatened Species 2010: e.T60265A12335766. Accessed at: https://www.iucnredlist.org/species/60265/12335766.

Kalkman V.J., Boudot J.-P., Bernard R., Conze K.-J., De Knijf G., Dyatlova E., Ferreira S., Jović M., Ott J., Riservato E., Sahlén G. (eds). 2010. European Red List of Dragonflies. Luxembourg: Publications Office of the European Union. 28 pp.

Kalniòš M., Bernard R., Miíelsone I. 2011. Protected Aquatic Insects of Latvia Nehalennia speciosa (Charpentier, 1840) (Odonata: Coenagrionidae) // Latvijas Entomologs. Vol.50. P.41-54.

Karjalainen S. 2007. Sudenkorentojen (Odonata) uudet makuntahavainnot 2002-2007 [New provincial records of Finnish dragonflies (Odonata) in 2002-2007] // Sahlbergia. Vol.13. P.13-25.

Karjalainen S. 2019. Sudenkorennot. Dragonflies and Damselflies (Odonata) // Suomen lajien uhanalaisuus. Punainen kirja. P.355-357.

Karlsson T. 2011: Dvärgflicksländan Nehalennia speciosa i Sverige (Odonata: Coenagrionidae). [The Sedgling Nehalennia speciosa in Sweden (Odonata: Coenagrionidae).] // Entomologisk Tidskrift. Vol.132. No.3. P.129-140.

Kosterin O.E., Haritonov A.Yu., Inoue K. 2001. Dragonflies of the part of Novosibirsk Province east of the Ob'River // Sympetrum Hyogo. Nos 7-8. P.24-49.

Polevoi A.V., Humala A.E., Gorbach V.V., Uzenbaev S.D. 2009. Changes and additions to the list of rare and vulnerable insect species of Republic Karelia // Trudy Karel'skogo nauchnogo tsentra RAN. Biogeographia Karelii. No.1. P.90-97 [in Russian].

Przhiboro A.A. 2018. [Nehalennia speciosa (Charpentier, 1840)] // Red Data Book of Leningrad Province. Animals. St Petersburg: Papirus. P.217-218 [in Russian].

Schmidt B., Sternberg, K. 1999. Nehalennia speciosa (Charpentier, 1840), Zwerglibelle // Sternberg K., Buchwald R. (Hrsg.). Die Libellen Baden-Wurttembergs. Band 1: Allgemeiner Teil, Kleinlibellen (Zygoptera). Stuttgart: Eugen Ulmer. P.358-368.

Skvortsov V.E. 2010. The dragonflies of Eastern Europe and Caucasus: An illustrated guide. Moscow: KMK Scientific Press Ltd. 623 pp.

Tiensuu L. 1933. Sortavalan pitajan sudenkorennoiset // Vanamon Julkaisuja (Annales Soc. Zool.- Bot. Fenn. Vanamo) Helsinki. Vol.14. No.4. P.75-114.

Tikhomirov A.M. 2007. Nehalennia speciosa (Charpentier, 1840). // V.A. Isaev (ed.). Red Data Book of Ivanovo Province. Vol.1. Animals. Ivanovo: IPK "PresSto". P.24 [In Russian].

Valtonen P. 1980. Die Verbreitung der finnischen Libellen (Odonata) // Notulae Entomologicae. Vol.60. No.4. P.199-215.

Valle K.J. 1920. Zur Kenntnis der Odonatenfauna Finnlands // Acta Soc. pro Fauna et Flora Fennica. Vol.47. No.3. P.1-42.

Valle K.J. 1952. Die ostfennoskandieschen Odonaten (Zur Kenntnis der Odonatenfauna Finnlands VI) // Acta Entomologica Fennica. Vol.10. P.1-87. 